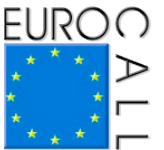

\title{
Mobile assisted language learning of less commonly taught languages: learning in an incidental and situated way through an app
}

\author{
Cristiana Cervini ${ }^{1}$, Olga Solovova ${ }^{2}$, \\ Annukka Jakkula ${ }^{3}$, and Karolina Ruta ${ }^{4}$
}

\begin{abstract}
Learning has been moving out of classrooms into virtual and physical spaces for over a decade now (Naismith, Lonsdale, Vavoula, \& Sharples, 2004). It is becoming mobile 'in space', i.e. carried across various domains (workplace, home, places of leisure), 'in time', as it encompasses different moments of the day, and in terms of 'learning purpose', which may be related to work, self-improvement or leisure (Vavoula \& Sharples, 2002). In line with the principles of learning in an informal, incidental and mobile way, an open source and geolocalised application for learning foreign languages with a smartphone is being implemented within Key Action 2 of the Erasmus Plus European framework by the project called ILOCALAPP - Incidentally Learning Other Cultures and Languages - (Ceccherelli et al., 2016). ILOCALAPP will result in an app to aid in learning Finnish, Italian, Polish and Portuguese embedded within their respective cultural practices. The target group is mobility students, so the app will be situated in the university city where international students arrive, i.e. the Finnish language content will unfold in Rovaniemi, Italian in Bologna, Polish in Poznań, and Portuguese in Coimbra. The learning content will blend in the students' everyday contexts, whereby the app would be used incidentally in a game-like manner, thus providing enjoyable learning moments throughout their daily activities in an informal way.
\end{abstract}

Keywords: MALL, incidental learning, geolocalisation, multilingualism, less commonly taught languages.

\footnotetext{
1. University of Bologna, Bologna, Italy; cristiana.cervini@unibo.it

2. University of Coimbra, Coimbra, Portugal; olga@ces.uc.pt

3. University of Lapland, Rovaniemi, Finland; annukka.jakkula@ulapland.fi

4. Adam Mickiewicz University, Poznań, Poland; karuta@amu.edu.pl
}

How to cite this article: Cervini, C., Solovova, O., Jakkula, A., \& Ruta, K. (2016). Mobile assisted language learning of less commonly taught languages: learning in an incidental and situated way through an app. In S. Papadima-Sophocleous, L. Bradley \& S. Thouësny (Eds), CALL communities and culture - short papers from EUROCALL 2016 (pp. 81-86). Research-publishing.net. https://oi.org/10.14705/rpnet.2016.eurocall2016.542 


\section{Introduction}

Measures on the promotion of lesser used languages in Europe have been established by the European Commission since the late 1980s. Languages spoken in the countries of ILOCALAPP partners fall within the multilingualism policies on Less Widely Used and Taught Languages in Europe (European Commission, 2011). The acknowledgement of the importance of informal learning in lifelong education within the EU, as well as the implementation of common policies for mobility by Erasmus Plus programme provide common political guidelines for the ILOCALAPP project.

Online and mobile technologies have opened up exciting new possibilities for study in higher education. Mobile learning can make boundaries between educational settings, life and work more permeable. Our app will build on mobile devices while exploiting their built-in sensors (e.g. GPS, gyroscope, accelerometer, camera), as well as an Internet connection, thus enabling to detect and identify user activities and trigger some contextual contents and activities related to specific geolocalised Points of Interest (POIs). As the user gets close to a POI, the app will upload relevant contents and activities (e.g. ordering food in a café, asking for directions). With the app, learning languages becomes more accessible in various situations, collaborative and participatory. By foregrounding cultural values and practices, it provides opportunities for authenticity, communicativeness and inclusion.

\section{Mobile technologies and learning of languages and cultures: some theoretical underpinnings}

We start off from the theories of situated and incidental learning where all learning is embedded in the learners' social, cultural and historical contexts, representing interaction with their lifeworlds (Lave \& Wenger, 1991). Integral to this process becomes participation in a community that shares certain cultural values, assumptions and rules, i.e. a community of practice. So in an app that supports mobility, the cultural identities of the student and surrounding community become especially important. Cultures and languages are viewed as mutually dependent - as parts of the complex language-culture nexus which is historically and ideologically situated (Risager, 2006). The app serves as an interactive device that mediates and sustains the process of discovering new cultures and languages, while learners get engaged in open and fluid social relations (Lankshear \& Knobel, 2006). 
The need of combining mobile technologies with language/culture learning led to creating an interdisciplinary methodological framework at the interface between multimedia design, digital literacy and language teaching/learning. The resulting framework is oriented around three interrelated thematic clusters: (1) collaborative and participatory, (2) integrated and situated, and (3) informal and incidental.

By developing a collaborative and participatory app, the ILOCALAPP team aimed to ensure an effective learner participation throughout all stages of the app development, from outlining its contents to the use and dissemination. Channels for user collaboration and participation were opened through active consultation (by carrying out surveys and focus groups with mobility students) and participant observation of users while being engaged with the preliminary app contents (through experience prototyping). The learning, use of the app and the content development are thus co-constructive (Castillo \& Ayala, 2012; Traxler \& Kukulska-Hulme, 2016).

The app will also be integrated and situated, so that its content is based on authentic and real-life situations, while the learning is context-aware. The context for ILOCALAPP is the daily student life in one of the partner university cities - well within the overall trend for mobile learning, which had evolved from learning with computers to being part of the ubiquitous use of mobile devices (through POIs and geolocalisation).

Finally, the app will be informal and incidental: both the contexts, contents and use of the app are situated outside the classroom and within the everyday activities of a mobility student (Laurillard, 2007; Silva, 2007). Units and exercises of formal learning are replaced by POIs, a flow of activities and game-like elements in the app contents.

\section{From theory to the content design}

Factors of diverse nature contribute to the efficacy of foreign language acquisition, from internal factors such as aptitude, age, cognitive styles, motivations, etc., to external ones, like sociocultural features of the contexts learners live in. The richness and variety of the linguistic input, as well as the significance of the communicative situation learners experience, play a crucial role in the process of spontaneous acquisition. To ensure its exploitability and usability, the input should be comprehensible (Krashen, 1985), so access to written and oral texts is essential 
before interaction. Mapped onto the core values (collaborative/participatory, integrated/situated, and informal/incidental), the linguistic acquisition principles have guided the ILOCALAPP team in the conception of authentic contents for each town, in order to provide useful materials for students' daily life actions and interactions for language learning.

Contents will be accessible through three different points of entry: 'In the place', 'Activities', and 'Culture'. The entry 'In the place' comprises nine categories as informed by the lived experiences of an Erasmus student in a new town: (1) Uni Life, (2) Getting around, (3) Food \& Drink, (4) Sights, (5) Entertainment, (6) Lifestyle, (7) Services, (8) Shopping, and (9) Me in... Each category includes sub-categories; for example, in 'Sights', users can explore POIs linked to the most relevant 'squares', 'monuments', and 'parks' in town, etc.

Me in... seems to be the most innovative category: an open space where users can personalise the app content by bookmarking their favourite linguistic and communicative resources. It provides the app users with a space to negotiate their own cultural identities and practices as well as find affinities with other users, thus building a community of practice.

Geolocalisation will also facilitate the content exploration thanks to active notifications about the different POIs. App users are expected to be inquiring cultural and historical information about the place, but are also encouraged to interact with other speakers in it. For this reason, the section 'Tips for talking' consists of suggestions of words and expressions useful and coherent with the local communicative situation. Simultaneously, the section 'Talk' will provide readymade sentences in a written/audio format, followed by prototypical answers.

A robust effort has been made to let typical situations of the Erasmus students inform the app content and also to foresee their potential difficulties in understanding written and oral content, considering the following challenges:

- the app is not strictly addressed to users of a certain level of proficiency, so readjustment will be needed to ensure the materials' authenticity;

- a valid interlinguistic and intercultural model will not be easy to achieve: mobility students learning Italian and Portuguese may count on intercomprehension and positive transfer, whereas most mobility students in Poznań and Rovaniemi are beginners in Polish and Finnish, so comprehension can constitute a major challenge. 


\section{Final considerations and conclusion}

One of the main challenges for the ILOCALAPP team resides in the fact that the app will be launched in 2018, thus needing a considerable foresight to produce an app that would still be appealing and relevant to the students' social, cultural and historical realities in 2018 and beyond. From a technical perspective, it is a multiplatform web app, designed according to human-computer interaction methodologies and built in standard technologies such as HTML5, CSS3 and standard scripting languages. Active ongoing contact with mobility students as well as their collaboration throughout all stages of the app development will be necessary to keep abreast of their lifestyle and potential changes under way. Mobile devices are ubiquitous and could be assumed to be present in everyday lives of mobility students in the future. Most importantly, the next generation of mobile learning is becoming increasingly 'context-aware' (Traxler \& Kukulska-Hulme, 2016). So ideally, students would see our app as part of their everyday lives to provide a pleasant moment of informal and incidental learning amidst their mundane and institutional activities. Apart from enhancing student mobility experience, the ILOCALAPP team wants the app to pave the way both for spontaneous, motivating and context-aware language learning as well as for cultural awareness.

\section{Acknowledgements}

This paper is based on the work developed within the ILOCALAPP Project (www. ilocalapp.eu). ILOCALAPP (Incidentally Learning Other Cultures And Languages through an APP) is a three-year Erasmus+ project carried out by a transnational consortium of four partners: the University of Bologna (Italy), the Adam Mickiewicz University (Poznań, Poland), the University of Lapland (Rovaniemi, Finland) and the Centre for Social Studies at the University of Coimbra (Portugal). The authors wish to express their gratitude to all project partners for their active and fruitful cooperation.

\section{References}

Castillo, S., \& Ayala, G. ( 2012). Mobile learning. In N. M. Seel (Ed.), Encyclopedia of the sciences of learning (pp. 2293-2295). Berlin: Springer.

Ceccherelli, A., Cervini, C., Magni, E., Mirri, S., Roccetti, M., Salomoni, P., \& Valva, A. (2016). The ILOCALAPP project: a smart approach to language and culture acquisition. The Future of Education Conference Proceedings (pp. 270-275). Firenze: Pixel Libreria Universitaria. 
European Commission. (2011). Policy recommendations for the promotion of multilingualism in the European Union. Brussels: Civil Society Platform on Multilingualism. http:// ec.europa.eu/languages/information/language-related-tools/civil-society-platformmultilingualism en.htm

Krashen, S. D. (1985). The input hypothesis: issues and implications. New York: Longman.

Lankshear, C., \& Knobel, M. (2006). New literacies: everyday practices and classroom learning. Maidenhead: McGraw Hill.

Laurillard, D. (2007). Pedagogical forms for mobile learning. In N. Pachler (Ed.), Mobile learning: towards a research agenda (pp. 153-175). London: WLE Centre, IoE.

Lave, J., \& Wenger, E. (1991). Situated learning. Legitimate peripheral participation. Cambridge: University of Cambridge Press. https://doi.org/10.1017/CBO9780511815355

Naismith, L., Lonsdale, P., Vavoula, G., \& Sharples, M. (2004). Mobile technologies and learning. Futurelab Literature Review Series, 11. Leicester: Leicester Research Archive.

Risager, K. (2006). Language and culture. Global flows and local complexity. Clevedon: Multilingual Matters.

Silva, P. M. (2007). Epistemology of incidental learning. PhD dissertation. Virginia Polytechnic Institute and State University.

Traxler, J., \& Kukulska-Hulme, A. (2016). Mobile learning: the next generation. New York: Routledge.

Vavoula, G. N., \& Sharples, M. (2002). KLeOs: a personal, mobile, knowledge and learning organisation system. In Proceedings of the IEEE International Workshop on Mobile and Wireless Technologies in Education (WMTE 2002). https://doi.org/10.1109/ wmte.2002.1039239 


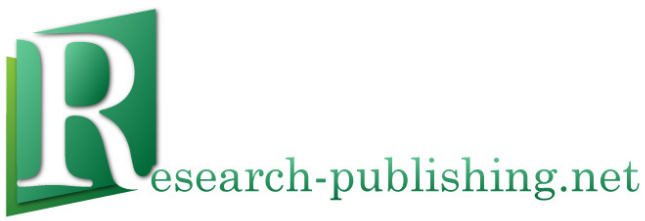

Published by Research-publishing.net, not-for-profit association Dublin, Ireland; Voillans, France, info@research-publishing.net

(C) 2016 by Editors (collective work)

(C) 2016 by Authors (individual work)

\section{CALL communities and culture - short papers from EUROCALL 2016 Edited by Salomi Papadima-Sophocleous, Linda Bradley, and Sylvie Thouësny}

Rights: All articles in this collection are published under the Attribution-NonCommercial -NoDerivatives 4.0 International (CC BY-NC-ND 4.0) licence. Under this licence, the contents are freely available online as PDF files (https://doi. org/10.14705/rpnet.2016.EUROCALL2016.9781908416445) for anybody to read, download, copy, and redistribute provided that the author(s), editorial team, and publisher are properly cited. Commercial use and derivative works are, however, not permitted.

\section{(9) $\Theta \Theta$}

Disclaimer: Research-publishing.net does not take any responsibility for the content of the pages written by the authors of this book. The authors have recognised that the work described was not published before, or that it is not under consideration for publication elsewhere. While the information in this book are believed to be true and accurate on the date of its going to press, neither the editorial team, nor the publisher can accept any legal responsibility for any errors or omissions that may be made. The publisher makes no warranty, expressed or implied, with respect to the material contained herein. While Research-publishing.net is committed to publishing works of integrity, the words are the authors' alone.

Trademark notice: product or corporate names may be trademarks or registered trademarks, and are used only for identification and explanation without intent to infringe.

Copyrighted material: every effort has been made by the editorial team to trace copyright holders and to obtain their permission for the use of copyrighted material in this book. In the event of errors or omissions, please notify the publisher of any corrections that will need to be incorporated in future editions of this book.

Typeset by Research-publishing.net

Cover design by (C) Easy Conferences, info@easyconferences.eu,www.easyconferences.eu

Cover layout by (c) Raphaël Savina (raphael@savina.net)

Photo "bridge" on cover by (C) Andriy Markov/Shutterstock

Photo "frog" on cover by (C) Fany Savina (fany.savina@gmail.com)

Fonts used are licensed under a SIL Open Font License

ISBN13: 978-1-908416-43-8 (Paperback - Print on demand, black and white)

Print on demand technology is a high-quality, innovative and ecological printing method; with which the book is never 'out of stock' or 'out of print'.

ISBN13: 978-1-908416-44-5 (Ebook, PDF, colour)

ISBN13: 978-1-908416-45-2 (Ebook, EPUB, colour)

Legal deposit, Ireland: The National Library of Ireland, The Library of Trinity College, The Library of the University of Limerick, The Library of Dublin City University, The Library of NUI Cork, The Library of NUI Maynooth, The Library of University College Dublin, The Library of NUI Galway.

Legal deposit, United Kingdom: The British Library.

British Library Cataloguing-in-Publication Data.

A cataloguing record for this book is available from the British Library.

Legal deposit, France: Bibliothèque Nationale de France - Dépôt légal: décembre 2016. 